\title{
Feminism and Emancipation: Influence of Feminist Ideas on Women's Socio-Economic and Political Liberation in Sri Lanka
}

\author{
A. M. M. Chandrika \\ School of Sociology, Central China Normal University, Wuhan, China \\ Email: malanichandrika42@yahoo.com
}

How to cite this paper: Chandrika, A. M. M. (2019). Feminism and Emancipation: Influence of Feminist Ideas on Women's Socio-Economic and Political Liberation in Sri Lanka. Sociology Mind, 9, 302-315. https://doi.org/10.4236/sm.2019.94020

Received: August 20, 2019

Accepted: October 20, 2019

Published: October 23, 2019

Copyright ( 2019 by author(s) and Scientific Research Publishing Inc. This work is licensed under the Creative Commons Attribution International License (CC BY 4.0).

http://creativecommons.org/licenses/by/4.0/

Open Access

\begin{abstract}
Study of women's socio-economic and political liberation in the academic arena is significant theme with continuous feminists' ideas in the modern world. Focusing the Asian patriarchal society like Sri Lanka, women's liberation is decided by gender disparities which emerged through socialization process, internalizing social norms, cultural values and expectations. Hence, in the traditional society, women were discriminated from high positions in society, political leadership, decision making and economic top management. However, with the spreading out of feminist ideas and changes that took place in Sri Lanka after independence of the country, some educated women started to address women's issues and developed a discourse regarding women's liberation in the contemporary society. The major objective of this study is to examine what are the challenges that women face in getting their socio-economic and political liberation in Sri Lanka, and to investigate how feminists contribute to achieve equal rights for women in the country. The study was based on secondary data gathered from literature surveys which are directly related to the issues addressed in this study. The study revealed that the factors affect discrimination of women from socio-economic and political sectors in contrast to males in the society. In Sri Lanka, traditional women have much less social, economic and political and domestic power than men. However, after independence, successive governments have devoted greatly to education, health and welfare programs. Due to this situation, the status of women in Sri Lanka has changed dramatically. At the same time, feminist scholars are showing that, women play a significant role in the family as homemakers and working women's contribution to the economic development of the country. Furthermore, they have emphasized the importance of equal rights of women in socio-economic and political sectors as well as women's liberation against the patriarchal views in the society. However, women are still facing several problems due to unequal opportunities of political partici-
\end{abstract}


pation, labor force and decision making in the country. To overcome this situation, it is important to increase feminist activities and should change their direction to empower women in all sections through policymakers in the country.

\section{Keywords}

Gender, Feminism, Emancipation, Sri Lankan Women, Feminist Writings

\section{Introduction}

Feminism is a social movement and political program aimed at ameliorating the position of women in society (Campbell, 2006). Feminist theory aims to understand the nature of gender inequality and focuses on gender politics, power relations and sexuality. Firstly, feminist ideas emerged in the western society and then expanded all over the world in different ways. Accordingly, these ideas expanded in the Asian societies and most scholars used these ideas to describe and criticize Asian patriarchal and traditional views as well as gender inequality. When considering the historical transformation of Asian patriarchal societies, women's position was very low and they did not have the liberty to even talk about their issues. Within this context, feminist writings and activities supported them to be aware of their rights in the world, and how they could get their liberation within the patriarchal concept in the society. In Sri Lanka, after 1970s, most scholars who addressed the women's issues in the country used these feminist ideas to gain women's liberation against the patriarchal viewpoint in the society. Socially, they opened a platform to address cultural factors and traditional attitudes that unreasonably affect women to come forward in society. Economically, they addressed the dual role of women as domestic workers and official workers as well as problems that they face in the economic sector such as low wages. Politically, they are trying to increase women's participation as leaders in the political sphere. Within this context, the present study attempts to discuss in depth the impact of feminist ideas and activities on women's liberation in the socio-economic and political sectors in Sri Lanka.

Furthermore, the present research study and research information can mainly have contextualized feminism in Sri Lanka and discourse of women in Asian academic framework, too. Therefore, the factors that illustrate in this research may open valuable directions to women research in the academic field.

\section{Methodology}

The study was based on secondary data gathered from literature surveys which are directly related to the issues addressed in this study.

\section{Significance of the Study}

Feminist movements and feminist activities can be considered as successful 
campaigns with regards to addressing women issues in male dominant Asian societies like Sri Lanka. Currently, it can be realized the women's empowerment process is in a successful way than in the past with the spread of feminist ideas and feminist activities in Sri Lanka. Within this context, it is important to further have active participation of feminist activists to develop women's economic and political strength in Sri Lankan society. Therefore, to encourage and evaluate those activities it is important to highlight feminist contribution with regards to developing women's emancipation and it is significant to investigate further needs of feminist activities for Sri Lankan society to build up women's socio-economic and political liberation. In addition to this, present study is more significant to the discourse of women's issues in the current academic framework socially, economically and politically.

\section{Theoretical Approach}

This paper is mainly based on liberal feminist theory. Feminism is an awareness of women's oppression and exploitation in society, at work and within the family. Feminist affirmative action requires that conscious action be taken to change this situation (Jayasinghe, 2004). The competing school of feminism has sought to explain gender inequalities through avariety of deep-rooted social processes, such as sexism, patriarchy, and capitalism. There are four fundamental feminist theoretical orientations describe by Alison Jaggar and Paula Rothenberg; Liberal feminism, Marxist feminism, Radical feminism and Socialist feminism (Jaggar \& Rothenberg, 1993). The primary means of feminism is human liberation. However, feminist theory shines light on social problems, trends and issues that are otherwise overlooked or misidentified by the historically dominant male perspective within "social theory". Key areas of focus within feminist theory include discrimination and exclusion on the basis of gender, objectification, structural and economic inequality, power and oppression and gender roles and stereotypes, among others (Crossman, 2019).

Liberal Feminism: Liberal feminism is a form of feminism that argues that equality for women can be achieved through legal means and social reform, and that men as a group need not be challenged. Liberal feminism is a somewhat conservative form of feminism by today's standards, although it is rooted classically in liberalism (Mackinnon, 1987). In addition to this, liberal feminism is a traditional perspective that was established as a part of the first wave of feminism. It is often the root of comparison when deconstructing contemporary conceptualizations of feminism. It argues that "society has a false belief that women are by nature less intellectually and physically capable than men" (Tong, 2009).

Socialist and Marxist Feminism: Socialist feminism was developed by Marks and Engels. Socialist feminists argued that gender inequality has arisen because of patriarchy and capitalism. Women's oppressions in general are problems of a capitalist society and therefore the remedy is in its termination. Under capitalism Engles pointed out that, material and economic factors underlie the 
subordination of women to men because patriarchy has its roots in private property. Furthermore, Engels argued that capitalism intensifies patriarchy-the domination of men over women-by concentrating wealth and power in the hands of a small number of men (Giddens, 1991).

Radical Feminism: Radical feminists believe that men are responsible and benefit from the exploitation of women. According to their analysis of patriarchy, women dominated by men are a central concern. Radical feminism recognizes the oppression of women as a fundamental political oppression in which women are classified as a lower class based on their gender.

\section{Discussion}

\subsection{Feminism and Women's Liberation: Sri Lankan Context}

The women's liberation movement was a collective struggle for equality that was most active during the late 1960s and 1970s. It required to free women from domination and male ascendancy. The women liberation movement is also sometimes seen as being the same as radical feminism because both were anxious one mancipation members of the society from unfair social structure. "Both have sometimes been characterized as a threat to men, particularly when movements use rhetoric about 'struggle' and 'revolution'. However, feminist theorists overall are actually concerned with how society can eliminate unfair sex differentiation. There is more to women's liberation than the anti-feminist fantasy that feminist are women who want to eliminate men" (Linda, 2019). Accordingly, "Feminism" and "women's liberation" emerged in western societies, and these terms seem to call up vision of aggressive women's movements associated with western societies. One has to agree that women in third world Asian societies do not seek the same emancipation that western women are struggling for. While acknowledging the fact that in developing countries too, society is male dominated, the critical problems that Asian women are confronted with revolve round economic explanation and cultural conditioning. Although the whole of women's issues cannot be universalized, there are some universal problems which beset womankind as a whole (Kiribamune, 1993). Hence, the feminist views helped Asian societies to construct equal rights for women against the patriarchal social context.

When considering the main characteristics of patriarchal societies, a patriarchy is defined as "a social system in which power is held by men, through cultural norms and customs that favor men and withhold opportunity from women". A society or social system is patriarchal to the degree that it promotes male privilege by being male dominated, male identified and male centered. It attributes different characteristics to men and women and exalts male qualities as superior. Patriarchy is structured violence along gender lines. Some examples can be given from Sri Lankan society for further understanding this situation.

\subsection{Women's Position in Sri Lanka: Traditional Framework}

To understand the influence of feminist ideas for women's liberation in Sri Lan- 
$\mathrm{ka}$, it is important to examine women's situation in the past. Some of the main causes of gender inequality are due to the patriarchal nature of the Sri Lankan culture and the historical effects of the unbalanced weight put on the value of males. Furthermore, gender inequality has also been continued by cultural practices, both legal and illegal, including the use of dowries and certain limiting marriage laws. In Sri Lankan society, dowries have been shown to have negative effects on women, while on the one hand they may enhance their marriage ability and allow them to gain in social status. It also places a severe of stress and pressure on the family of the bride to provide enough funds for the family of the groom. Not only that, material gifts will be given to the daughter for her wedding and the grooms family will be compensated for what is sometimes deemed as the burden of the wife into the family. This also can lead to gender based violence and domestic abuse when the husband or his family believes the dowry was not sufficient.

The other example is women's employment. Historically, women in Sri Lanka have had reduced access to quality employment, and even if they obtain a job, they are paid far less and are subject to more harassment and limitations as compared to males doing the same jobs. The Sri Lankan labor market is deeply separated and leaves little opportunity for women to gain access to jobs. Because of patriarchal policies embedded in the history of this region, women are over-represented in the low-paid, laborious industries of the country. Especially, it is in these jobs that women face a disproportionate amount of labor discrimination and lack of proper wages in the name of international competitiveness and the production of additional jobs.

In addition to this, when the subject of occupation in the country is considered, there are problems that can be highlighted regarding gender inequality. In many cases females are deprived of equal access to jobs, even when they are not well paid or of high status. The unemployment rate for women in Sri Lanka was $13 \%$ in 2012, which was six times higher than that of males, according to the Labor Force Survey taken by the department of census and statistics (Department of census and statistics, 2012). The collective action and inaction of different nations to take a stand on equal labor rights especially for women is a more complicated issue than commonly described, as pointed out by some feminist scholars. According to some economic feminists, for many of the women in the industries, these jobs prove to empower them and allow for additional independence in place of simply limiting their rights. However other studies suggest that these low-paying heavy-labor jobs are simply taken on by women because of economic necessity and do not contribute to their societal independence within the patriarchal society.

When focusing on the education sector, gender inequality can be highlighted as an issue in Sri Lankan society in the past. Most of the feminist scholars highlighted that empowering women through education has important implications for women's economic empowerment, access to information, knowledge and skills and decent and remunerative work (Jayawardana, Wijerathna, Wanasun- 
dara, \& Vitarana, 2007). Viewed in a wider sense, education enhances women's capability to make choices, develops self-confidence, decision making power and autonomy. But, yet women still continue to struggle with the same old questions of gender inequality in Sri Lanka. In addition to experiencing high levels of gender based violence, women's labor force participation is half of that of men and double their unemployment rates as discussed above in this paper. We all know that education is often championed for its transformative possibilities related to liberation, empowerment, social justices, individual freedoms, human rights and the reduction of social inequalities such as gender inequality. From this perspective, education is regarded as a means that will enable learners to think critically and have the ability to challenge the status quo (Thirusica, 2016). Hence, education is the main instrument for women to increase their social status. But Sri Lankan classrooms are often embedded with gender boundaries that reproduce powerful patriarchal hierarchies in the past. Accordingly, the patriarchal views and traditional attitudes regarding women in Sri Lankan society have highly influenced gender inequality in the past. However, with regard to this situation in modern society, some positive changes can be identified in some sectors such as education and health, because in those sectors women have already achieved their equal rights compared to other sectors.

A recent study claims that $64 \%$ of professionals in Sri Lanka are women, according to statistics released by the Census and Statistics Department (Waduge, 2017). In numbers, it amounts to 336,586 women professionals against 174,644 males. Let us also not forget that the largest numbers of outsourced workers abroad are housemaids (Waduge, 2017). 1.7 million Sri Lankans are employed abroad of which 36.78 are women. Quite a number of companies that take graduate interns prefer female interns as their attitude towards work is more positive and they are ready to take on any role (Waduge, 2017). Random views sought from different employers too gave the impression that women were more productive than their male counterparts (Waduge, 2017). Accordingly, in the present, Sri Lankan women have a significant social position in some sectors, and the social changes in the Sri Lankan society in its historical transformation can be identified. And also it is very clear that modern ideas highly impact on these changes and here I will attempt to analyze the ways in which feminist ideas influence these positive changes in the society.

\subsection{Impact of Feminist Ideas on Women's Liberation in Sri Lanka}

Taking into consideration of Sri Lankan women's liberation, it has increased with social changes which took place in Sri Lanka after independence. However, it should be mentioned that there was also some women's collective activism under the British colonialism. Kumari Jayawardana and Malathi De Alwis stated that "Be it in the sphere of religious, social, economic or political reforms, Ceylonese women have been at the forefront during the nineteenth and early twentieth centuries" (Jayawardana, Kumari, De Alwis, \& Malathi, 2002). Considering women activities, there are some organizations which started to deal with wom- 
en's issues in various fields. Among those organizations, feminist politics entered and influenced the agendas of such organizations basically only after the 1970s with the UN declaring International Years of Women (1975) and UN Decade for Women (1976-85) (Wickramagamage, 1999). On the one hand, after independence, Sri Lankan society changed through improvement of economy and that situation made women to involve in economic activities than in the past. On other hand, at the same time women organizations and feminist activists created a discourse regarding women's rights and empowerment against the male dominant concept of the society. This major shift in thinking regarding women's status and women issues in Sri Lanka occurred in the 1970s.

\subsubsection{Feminist Viewpoint of Gender Inequality in Political Sphere}

In Sri Lanka, women writers addressed the root causes of gender inequality in the society and they created a discourse against patriarchal views in the society. Through these writings, representation of women in political institution was identified as a critical issue of concern for women in Sri Lanka in the late 1970s; women's organizations individually and collectively have undertaken initiatives to address this issue. One of the articles to explore the issue of women and politics in Sri Lanka and obstacles faced by women in entering politics was by Wimala de Silva. Her chapter on "Political Participation and Decision Making" appeared in a seminal publication called "The Status of Women" initiated by a group of university women and published by the University of Colombo in 1979. This article provided a rich and nuanced analysis of the problem of women in politics. Since then, has been an explosion in research studies and publications on this issue. Those publications cover a wide range of issues including, the history of the struggle for women's franchise, the role and status of women within political parties, women's pathways to politics in Sri Lanka, analysis of obstacles to women's political participation and representation, implementation of quotas for women within different electoral systems. Several surveys have also sought to explore the issue of women and politics commencing with a survey done by CENWOR (Centre for Women's Research) in 1994. These surveys have sought to ascertain levels of political participation and perceptions about women's participation and representation in politics. These studies on the topic of women's political participation and representation have inspired and provided impetus to much of the activism to increase women's representation in Sri Lanka. Further the feminist organizations organized several training programs for increased women's political participation. Especially, to increase women's representation in political institutions, there has been on training and capacity building of women to take on political leadership. But, still in Sri Lanka, women's participation in politics is very low. This can be seen in Table 1 of "Proportion of Seats held by Women in the National Parliament 1947-2014".

Out of 225 Parliamentary seats, only 13 are occupied by women members. 
Although women constitute over 50 percent of the population, women's representation in Parliament has been far below10 percent at any given period. Not only in parliament, even in other higher institutions of political sector women's participation is also very low according to historical transformation. This can be seen in the following Table 2 of "Representation in the Executive by Secretaries to Ministries, 1980-2014".

Table 1. Proportion of Seats held by Women in the National Parliament 1947-2014.

\begin{tabular}{cccc}
\hline Year & Total No. & Women No. & \% of Women \\
\hline $1947-1952$ & 101 & 3 & 3.0 \\
$1952-1956$ & 101 & 2 & 2.0 \\
$1956-1959$ & 101 & 4 & 4.0 \\
1960 (April) & 157 & 3 & 1.9 \\
1960 (July)-1964 & 157 & 3 & 1.9 \\
$1965-1970$ & 157 & 6 & 3.8 \\
$1970-1977$ & 157 & 6 & 3.8 \\
$1977-1989$ & 168 & 11 & 6.5 \\
$1989-1994$ & 225 & 13 & 5.8 \\
$1994-2000$ & 225 & 12 & 5.3 \\
$2000-2001$ & 225 & 9 & 4.0 \\
$2001-2004$ & 225 & 10 & 4.4 \\
$2004-2010$ & 225 & 13 & 5.8 \\
$2010-2014$ & 225 & 13 & 5.8 \\
\hline
\end{tabular}

Sources: Parliamentary Handbook.

Table 2. Representation in the executive by secretaries to ministries, 1980-2014.

\begin{tabular}{cccc}
\hline Year & Total No. & Women's No. & \% of Women \\
\hline 1980 & 26 & 0 & 0.0 \\
1990 & 29 & 0 & 0.0 \\
1993 & 32 & 0 & 0.0 \\
1994 & 28 & 0 & 0.0 \\
1995 & 20 & 1 & 5.0 \\
1997 & 31 & 1 & 3.2 \\
1999 & 31 & 1 & 3.2 \\
2000 & 35 & 2 & 5.7 \\
2002 & 55 & 6 & 10.9 \\
2004 & 41 & 5 & 12.2 \\
2007 & 56 & 6 & 10.7 \\
2010 & 53 & 10 & 18.8 \\
2014 (June) & 60 & 12 & 20.0 \\
\hline
\end{tabular}

Source: Presidential Secretariat. 
Taking this situation into consideration, most feminist and other scholars have pointed out that, although there are some equal opportunities in some sectors, there is no equal opportunity in political sector and they highlight some problems and reasons for the situation. They are;

1) Shortage of women who wish to take part in politics; politics is considered to be a men's realm.

2) Patriarchal culture; traditionally women were excluded from high positions.

3) Lack of experienced women; most women have been forced to have "feminine" occupations and it is hard to enter politics through such occupations.

4) Woman's family responsibility; It is often hard to manage time and energy between family and politics.

5) Religion; Social division of gender roles legitimized by religious doctrine and practice act to control female potential.

Discussing Sri Lankan women's achievements and challenges, N.S. Gunawardena highlights that "Stereotyping of women as having no role in politics, is also perpetuated through the popular media. An example would be the recent provincial government elections in 2013, at which the media was quick to point out that most of the women candidates were actresses or from political families. Although there were almost as many young men who were actors or linked to political families, they were not subject to the same level of scrutiny. Stereotyping leads to most women not only displaying a lack of interest and confidence to engage in politics but considering politics as an illegitimate activity for themselves" (Gunawardena, 2015).

Within this context, feminist writings and activities have helped to bring about further changes of the society. For example, they highlighted women's problems in various sectors like economic, political, social and cultural, and addressed the root causes of gender inequality and they created a discourse against patriarchal views in the society which made the role of women and gender relations visible in society in general. In addition to this, it exposed the dark side of family life, helping to free women and children from domestic violence and abuse. It has increased people's awareness of the inequalities created by gender. Furthermore, they show how gender roles are socially constructed. It can be highlighted by some examples from modern Sri Lankan writings, as to how feminist writers address these issues. Referring to feudal, colonial capitalist formations in Sri Lanka, Hema Gunathilake highlights the barriers to women's emancipation and empowerment. This is a struggle against accepted custom, values, attitudes and prejudices arising from various historical experiences. Women are taught to accept certain institutions as "natural" while the man-made codes of behavior provide the seeming rational (Jayawardena, 1976). Many women have defined their status as their destiny, because it is inscribed in their religious beliefs, highlighting the vital importance of women's empowerment. Swarna Jayaweera argues: The education process should be consciously used to empower women to challenge doctrinaire practices and rituals that perpetuate the subordination of 
women in the family through marriage practices and acceptance of patriarchy in household decision making (Jayaweera, 1995). One such patriarchal practice that disadvantages women economically is the distribution of the family estate. From the past time, estates have been inherited along the patriarchal kinship line. Daughters receive a dowry while sons enjoy the family estate, although the Kandyan law clearly accepts women's property right (Ponnambalam, 1982). Therefore, despite several changes have been made in Sri Lankan property law the normal practice remains patriarchal, with the result that is difficult for women to obtain loans from formal lending institutions, such as banks because even at present the land and other assets are mainly in the husband's name.

\subsubsection{Feminist Standpoint of Women's Social Liberation through Education}

Where female education sector is concerned, many women writers such as Swarna Jayaweera, C. Wickramagamge have pointed out the importance of education equality to avoid women's unemployment in the country. The standard of education in Sri Lanka, even before independence, has been exemplary. Free education was granted universally to males and females shortly after independence. Even textbooks have been provided free of charge since the 1980s. Gender equality in participation in the formal education system has been the case for some time, though since 2000 the number of females has surpassed the number of males (Wickramagamage, 2012). In 1950, the number of girls participating in the formal education system was $18.7 \%$; by 1978 , the figure had risen to $37.7 \%$; and in the year 2000, girls' participation reached 51\% (Wickramagamage, 2012). This trend has been prevalent as well in the secondary and post-secondary education spheres (School Census-2008 Preliminary Report). As a result of this trend, women have gained much ground in the ranks of highly paid professions in the country. In the medical, management and banking sectors, women are well represented in comparison to men. In the universities today, female undergraduates do extremely well in the disciplines of humanities and social sciences, law, management studies, and medicine and science, Table 3.

In fact, female students consist of $60 \%$ of the undergraduate population in the Sri Lankan university system (Sri Lanka University Statistics, 2013). When investigating the economic sector, women's participation in the economy is considered to be, by and large a good thing, synonymous with empowerment, liberating women from their traditional care-giving specialism and the restrictions of patriarchal gender relations, and giving them equal opportunities with men. Feminists have critiqued this assumption, seeing it as based on a "universal breadwinner model" that urges women to follow a trajectory of employment similar to that of men (Folbre, 2007). However, many development programs are predicated on this supposition. The approach also ignores women's responsibility for care, and fails to see how this dual responsibility often makes employment an additional "burden" rather than a means of empowerment. 
Table 3. Number of Undergraduates entrants by Academic Stream and Sex 2011/12.

\begin{tabular}{ccccc}
\hline \multirow{2}{*}{ Academic Stream } & \multicolumn{4}{c}{ 2011/12 } \\
\cline { 2 - 5 } & Men & Women & Total & \% of Women \\
\hline Arts & 1866 & 7546 & 9412 & 80.2 \\
Management Studies & 2034 & 2763 & 4797 & 57.6 \\
Commerce & 261 & 408 & 669 & 61.0 \\
Law & 79 & 369 & 448 & 82.4 \\
Science & 1769 & 2726 & 5495 & 49.6 \\
Medicine & 559 & 812 & 1371 & 59.2 \\
Dental Science & 49 & 73 & 122 & 59.8 \\
Veterinary Science & 47 & 101 & 148 & 68.2 \\
Agriculture & 446 & 886 & 1332 & 66.5 \\
Engineering & 1399 & 357 & 1756 & 20.3 \\
Architecture/Quantity Surveying & 249 & 255 & 504 & 50.6 \\
Computer Science & 756 & 719 & 1475 & 48.7 \\
Paramedical Studies & 241 & 565 & 806 & 70.1 \\
Indigenous Medicine & 111 & 336 & 447 & 75.2 \\
Fashion Design/Transport and & 68 & 58 & 126 & 46.0 \\
Logistics Management & 1934 & 17,974 & 28,908 & 62.2 \\
Total & & 6079 & & \\
\hline
\end{tabular}

Sources: Sri Lanka University Statistics 2012. University Grant Commission.

However, feminist scholars argue the importance of women's education for developing their social status and social positions which are related to the social liberation. They highlighted the main barriers for women's social status such as cultural attitudes and patriarchal views of the country. Feminist scholars have created a discourse with regards to women's capabilities and their social rights in relation to their social mobility. Hence, feminist activists have emphasized the importance of educational strength for women to develop their social liberation in all spheres.

\subsubsection{Feminist Perspective on Women's Economy}

Focusing the economic situation of women, in Sri Lanka, in both the urban and rural environments, women have long been subject to discrimination in wages and salaries. In the rural sector, agrarian female workers receive approximately half the wage paid to male co-workers for the same labor. For example, in the small-holder tea sector, a female weeder is paid less than the wage of a male weeder. In the urban sector, a female garbage collector or sanitary laborer is also given a relatively lower salary than their male counterparts. Female domestic servants, in particular, have been harshly exploited by their employers, as Kumari Jayawardena points out: There are no laws regarding wages, hours of work and conditions for domestic servants, with the result that women and girls in 
domestic service are often grossly underpaid and receive much lower wages than men servants although performing as hard work (Jayawardana, 1976). This situation persists to the present day. Female domestic servants may have to work 15 to18 hours per day for a meager pay. However, the male domestic servant earns somewhat better pay for what are often relatively easier tasks. So even at present, this issue remains visible in many sectors of the country (Jayaweera, Wijerathna, Wanasundara, \& Vitarana, 2007). Within this context, Kumari Jayawardana, through her writings, highlighted that, "women should be emancipated, have equal political, legal and economic rights, which include equal access to education, employment and political decision making and that in the whole process of economic growth, women should be 'integrated in to development', by bringing them in to new avenues of employment and income generating projects" (Jayawardana, 1986). Not only that, she further argued "there is a tacit assumption that the status of women can be improved by making them economically active members of society, by making them, even in a restricted sense, economically independent. Besides the income generating activities on a self-employment basis, there is also an emphasis on drawing women into the labor force, e.g. into tourist related activities, into the free trade zone, into the Middle East as housemaids but there is no questioning of the traditional patriarchal structures of society. Therefore, the relative economic independence of the women does not contribute to her emancipation. She, in fact, becomes doubly, oppressed; she has to bear the double burden of (paid) wage work and (unpaid) domestic labor" (Jayawardana, 1986). Hence, she suggested that the developmental approach may therefore result in binding women more firmly to her subordinate status (Jayawardana, 1986). In addition to this, she mentioned that women are, in fact being integrated into a process of development that still continues to be exploitative and oppressive as it is male dominated and male oriented (Jayawardana 1986).

Taking into consideration the influence of feminist ideas and especially feminist writings on women's liberation in Sri Lanka, we can highlight various types of research studies with reference to the present research in the Sri Lankan context; some studies have focused on social, political and economic perspectives and the other studies have directly focused on education health and other issues of women.

\section{Conclusion and Recommendations}

Feminism is one of the most successful campaigns all over the world regarding women emancipation and it can be recognized and acknowledged in every developed country and in many developing nations, too. Social policy has been put in place to ensure that women are treated as equals in the workplace and education. There aren't legislations put in place for family because that is more cultural. However, the impact of feminism (liberal) has resulted in a change in female outlook and aspirations. Feminism expanded in Asian societies against the tradi- 
tional patriarchal views and feminist writing has highly affected women's liberation in Asian societies. It is evident that in Sri Lanka, feminist ideas have contributed women to achieve their socio-economic liberation in the society. In Sri Lanka, in terms of their standard of living and social status, many educated Sri Lankan women enjoy a moderate level as far as participation in the socio-economic and cultural spheres are concerned. Further, women's representation in some of the highly paid professions, such as doctors and university lecturers is above or equal to that of males. However, this encouraging picture of economic success does not depict a cross-section of the wide range of women's socio-economic experiences in Sri Lanka. Nevertheless, it can still be identified that in many areas, women lack opportunities for training and advancement and less productive or socially under-valued employment, and fated to poverty. The subordination of such women in Sri Lanka is closely related to the lack of opportunities and the sexual division of labor.

In conclusion, women in Sri Lanka enjoy important achievements and, equally so, face major challenges. There is clear evidence from the fields of health and education that, promoting general equality in policies and programs as well as gender specific interventions, help women achieve their full potential. When considering those achievements of Sri Lankan women, it should be mentioned that feminist ideas and most of feminist writings help to establish and be aware of women's rights and their capabilities. However, focusing on women's challenges like political inequality in present society, it should be emphasized that we need more campaigns for increasing women's liberation in Sri Lanka.

Furthermore, it is important to recommend here that, feminist activities should be increased and their direction to empower women in all sections should be changed through policymakers in the country. Strong campaigns should be created to make aware of socio-economic and political rights of women who are at all levels of the country such as rural and uneducated women. Furthermore, women studies should be addressed to people who are not willing to change and are still embedded with patriarchal attitudes in the country in order to further facilitate women's liberation.

\section{Conflicts of Interest}

The author declares no conflicts of interest regarding the publication of this paper.

\section{References}

Campbell, A. (2006). Feminism and Evolutionary Psychology. In J. H. Barkow (Ed.), New York: Oxford University Press.

Crossman, A. (2019). Feminist Theory.

https://www.thoughtco.com/feminist-theory-3026624

Folbre, N. (2007). Measuring Care: Gender, Empowerment, and the Care Economy. Journal of Human Development, 7, 183-199. 
https://doi.org/10.1080/14649880600768512

Giddens, A. (1991). Modernity and Self Identity, Self and Society in the Late Modern Age. Cambridge: Polity Press.

Gunawardena, N. S. (2015). Women in Sri Lanka: Achievements and Challenge. Journal of the College of Community Physicians of Sri Lanka, 20, 4-25.

https://doi.org/10.4038/jccpsl.v20i1.8067

http://www.researchgate.net/publication

Jayasinghe, V. (2004). A Feminist Perspective in Sri Lanka. Pace Printers, Rajagiriya.

Jayawardana, K. (1986) Feminism in Sri Lanka in the Decade, 1975-1985. Colombo: Women's Education Center.

Jayawardana, K., \& De Alwis, M. (2002). The Contingent Politics of the Women's Movement in Sri Lanka after Independence. In J. Swarna (Ed.), Women in Post-Independence Sri Lanka (p. 245). New Delhi: Sage Publication.

Jayawardena, K. (1976). Women and Employment, Economic Review (pp. 14-15). Colombo: People's Bank Publication.

Jayaweera, S. (1995). Women Education and Development, Economic Review (pp. 15-21). Colombo: People's Bank Publication.

Jayaweera, S., Wijemanne, H., Wanasundera, L., \& Vitarana, K. M. (2007). Gender Dimensionsof the Millennium Development Goals in Sri Lanka. Colombo: Centre for Women's Research (CENWOR).

Kiribamune, S. (1993). Reconciliation of Roles: Women, Work and Family in Sri Lanka, ICES Sri Lanka Studies Series (p. 17). New Delhi: International Centre for Ethnic Studies in Association with NORAD and NAVRANG.

Linda, N. (2019). Women Liberation Movement, Definition and Overview. https://www.thoughtco.com/womens-liberation-movement-3528926

Mackinnon, C. A. (1987). Feminism Unmodified: Discussion on Life and Law, Harvard.

Ministry of Education (2008). School Census-2008 Preliminary Report. Colombo: Ministry of Education. http://www.statistics.gov.lk/education/PreliminaryReport-2008.pdf

Ponnambalam, S. (1982). Law and the Marriage Relationship in Sri Lanka. Colombo: Stamford Lake Publication.

Thirusica, K. (2016). Teaching Gender Inequality in Sri Lanka. https://www.opendemocracy.net/5050/tursica-kovinthan/teaching-gender-inequality-t extbox-and-traditions-in-SriLanka

University Grants Commission of Sri Lanka (2013). Sri Lanka University Statistics 2013. http://www.ugc.ac.lk/en/component/content/article/1418-sri-lankauniversity-statistics2013html

Waduge Shenali, D. (2017). Role of Women in Sri Lanka and Globally. http://www.ft.lk/article/591418/Role-of-women-in-Sri-Lanka-and-globally

Wickramagamage, C. (1999). Sri Lankan Organization for Women: A Critical Appraisal. In K. Sirima (Ed.), Womenand Politics in Sri Lanka: A Comparative Perspective. Kandy: International Center for Ethnic Studies.

Wickramagamage, C. (2012). A Silent Revolution? Free Education in Sri Lankan Women. https://www.colombotelegraph.com/index.php/a-silent-revolution-free-education-andsri-lankan-women 